\title{
CHANGES IN THE BLOOD CHEMISTRY IN CONGENITAL HYPERTROPHIC PYLORIC STENOSIS AND THEIR CLINICAL SIGNIFICANCE.
}

BY

STANLEY GRAHAM, M.D., and NOAH MORRIS, M.D.

(From the Dept. of Pædiatrics, Glasgow University, and the Biochemical Dept., Royal Hospital for Sick Children, Glasgow.)

A fairly extensive literature is accumulating regarding the clinical symptoms and chemical findings in cases of high intestinal obstruction, and particularly when the obstruction is situated at the pylorus. Hartmann and Smyth ${ }^{1}$ have recently published an exhaustive report of a series of investigations in infants suffering from vomiting due to various causes. More observations, however, have been made in the adult, but the bulk of the published work is a record of the study of the condition as experimentally produced in animals.

In 1918, McCann² showed that the plasma $\mathrm{CO}_{2}$ combining power of the blood was greatly increased after experimental obstruction of the pylorus. Two years later, McCallum ${ }^{3}$ and his co-workers demonstrated the same phenomenon and indicated its association with a fall in the chloride content of the blood. This they explained as being due to loss of chloride by the vomiting of the gastric juice which in turn led to an increase of the plasma $\mathrm{CO}_{2}$ to make good the deficiency of acid radicles. These same investigators found that the onset of tetany, which invariably occurred, could be prevented by intravenous administration of sodium chloride. Hastings, Murray and Murray ${ }^{4}$, Haden and $\mathrm{Orr}^{5}$ and Gamble ${ }^{6}$ have also published papers throwing further light on the condition. Brown, Eusterman, Hartmann and Rowntree ${ }^{7}$ described similar chemical findings in duodenal obstruction in the adult and Ellis ${ }^{8}$ demonstrated the presence of alkalæmia in two cases of intestinal obstruction. An identical picture was shown to be present in cases of duodenal ulcer after intensive alkali treatment especially in the presence of impaired renal function (Hardt and Rivers ${ }^{9}$ ).

In the present communication we wish to record the observations both clinical and chemical made during a study of congenital hypertrophic pyloric stenosis extending over the past four years. It is obvious that because of the age of the patients and the severity of the condition, the investigations had of necessity to be less complete than desired. In all: over fifty cases were studied but we propose to give only such details as are relevant for correlating the various findings.

Before we proceed to analyse our results, it will be of advantage to give a brief resumé of these findings which, on the whole, are in accord with those of other workers. A most striking and probably the only important clinical manifestation of the presence of an alkalosis in these cases is the depressed breathing. This may be evidenced in one or more of the following three ways. First, there may be a shallow type of respiration, so shallow in fact that even with the bell of the stethoscope piaced in front of the nose and mouth, it is 
often very difficult to hear the respirations. Secondly, the rate is frequently diminished, often to six or eight times per minute, and thirdly, there are wellmarked and often alarming periods of apnœa followed by three or four shallow respirations producing a typical Biot type of respiration. Most often, all three manifestations are present at the same time. At this point we would mention that we believe this condition to be present at some time in practically every case of pyloric stenosis in infancy. Coupled with this respiratory depression there exists a general lethargy, giving one the impression that the infant is under the influence of a hypnotic drug. In one instance, a baby was brought to hospital because the mother had noticed undue quietness. Recognition of the depressed breathing raised the suspicion of pyloric stenosis although the infant had not vomited on any single occasion. On examination typical gastric peristalsis was evident together with a palpable pyloric tumor. The diagnosis of pyloric stenosis was ultimately confirmed post mortem by the presence of a hypertrophied pylorus.

The biochemical examination of the blood shows usually a decrease in chlorides and an increase in the total $\mathrm{CO}_{2}$ content and, less frequently, in the non-protein nitrogen. As a rule, these three findings are present together but the variations from the normal in each are not necessarily of the same degree. Table I gives some results which will serve to indicate this variation. In several cases, the fixed base of the serum was also determined (Table 2), and it will be seen that it is usually within normal limits (149-162 mM per litre) although occasionally it is slightly reduced.

TABLE 1

GENERAL BIOCHENICAL FINDINGS IN THE BLOOD IN PYLORIC STEXOSIS.

\begin{tabular}{|c|c|c|c|c|c|c|c|c|c|c|c|}
\hline \multirow{2}{*}{\multicolumn{2}{|c|}{ Name }} & \multirow{2}{*}{$\begin{array}{c}\text { Age } \\
\text { in } \\
\text { weeks }\end{array}$} & \multicolumn{2}{|c|}{ Total $\mathrm{CO}_{2}$} & \multicolumn{2}{|c|}{$\begin{array}{l}\text { Chlorine } \\
\text { (CI) }\end{array}$} & \multirow{2}{*}{$\begin{array}{c}\text { Non- } \\
\text { protein } \\
\text { nitrogen } \\
\text { mgm. per } \\
\text { cent. }\end{array}$} & \multirow{2}{*}{$\begin{array}{l}\text { Excess } \\
\text { non-prot. } \\
\text { nitrogen } \\
\text { (mM. per } \\
\text { litre) }\end{array}$} & \multirow{2}{*}{$\begin{array}{c}\left(\mathrm{O}_{2}+\mathrm{Cl}\right. \\
(\mathrm{mM} \text {. per } \\
\text { litre })\end{array}$} & \multirow{2}{*}{$\begin{array}{c}\mathrm{CO}_{2}+\mathrm{Cl} \\
+ \text { excess } \\
\text { N.P.N. } \\
(\mathrm{mM} . \text { per } \\
\text { litre) }\end{array}$} & \multirow{2}{*}{$\begin{array}{l}\text { Respir. } \\
\text { rate } \\
\text { (per } \\
\text { min.) }\end{array}$} \\
\hline & & & $\begin{array}{l}\text { Vol. } \\
\text { per } \\
\text { cent. }\end{array}$ & $\begin{array}{l}\text { mM. } \\
\text { per } \\
\text { litre }\end{array}$ & $\begin{array}{l}\operatorname{mg} m . \\
\text { per } \\
\text { cent. }\end{array}$ & $\begin{array}{l}\text { mM. } \\
\text { per } \\
\text { litre }\end{array}$ & & & & & \\
\hline R. (C. & $\ldots$ & 8 & $1+(0 \cdot 5$ & 63 & 140 & 40 & 46 & 2 & 103 & 105 & 18 \\
\hline N. R. & $\ldots$ & 4 & $140 \cdot 0$ & 63 & 180 & 51 & 80 & 8 & 114 & 122 & 16 \\
\hline A. M. & $\ldots$ & 8 & $83 \cdot 1$ & 37 & 210 & 60 & 32 & 一 & 97 & 97 & 40 \\
\hline W. G. & $\ldots$ & 6 & $85 \cdot 0$ & 39 & 190 & 54 & 35 & - & 93 & 93 & 24 \\
\hline M. M. & $\ldots$ & 12 & $62 \cdot 5$ & 28 & 330 & 94 & 60 & 5 & 122 & 127 & 40 \\
\hline M. A. & $\ldots$ & 8 & $125 \cdot 6$ & $\tilde{5} 6$ & 110 & 31 & 145 & 20 & 87 & 107 & - \\
\hline A. $W$. & $\ldots$ & 7 & $110 \cdot 2$ & 50 & 170 & 49 & 63 & 5 & 99 & 104 & 26 \\
\hline E. M. & $\ldots$ & 8 & $100 \cdot 5$ & 45 & 160 & 46 & 86 & 9 & 91 & 100 & 12 \\
\hline J. K. & $\ldots$ & 6 & $91 \cdot 8$ & 41 & 160 & 46 & 50 & 3 & 87 & 90 & 24 \\
\hline J. McK. & $\ldots$ & 8 & $112 \cdot 0$ & 50 & 220 & 63 & 32 & - & 113 & 113 & - \\
\hline A. C. & $\ldots$ & 3 & $113 \cdot 0$ & 50 & 240 & 69 & 34 & 一 & 119 & 119 & 10 \\
\hline G. H. & $\ldots$ & 7 & $95 \cdot 8$ & 43 & 190 & 54 & 75 & 7 & 97 & 104 & 14 \\
\hline W. A. & $\ldots$ & 3 & $103 \cdot 7$ & 46 & 300 & 86 & 38 & - & 132 & 132 & - \\
\hline W. A. & $\ldots$ & 4 & $148 \cdot 0$ & 66 & 130 & 37 & 183 & 27 & 103 & 130 & - \\
\hline
\end{tabular}


TABLE 2.

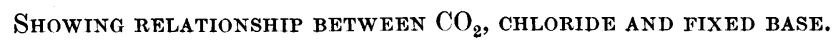

\begin{tabular}{|c|c|c|c|c|c|c|c|c|c|c|c|}
\hline Name & & J.McK. & J.P. & T.S. & G.C. & W.B. & A.B. & M.McP. & D.F. & R.S. & E.F. \\
\hline $\mathrm{CO}_{2}$ (mM. per litre) ... & $\cdots$ & 51 & 53 & 56 & 21 & 50 & 54 & 28 & 49 & 45 & 46 \\
\hline Cl (mM. per litre) ... & $\ldots$ & 63 & 54 & - & 70 & - & 34 & 83 & - & - & 60 \\
\hline Fixed base (mM. per 1.) & $\ldots$ & 144 & 151 & 150 & 160 & 159 & 152 & 154 & 153 & 143 & 161 \\
\hline
\end{tabular}

CHART I.

Showing Relationship between Respiratory Rate and Total $\mathrm{CO}_{2}$ Content of Blood.

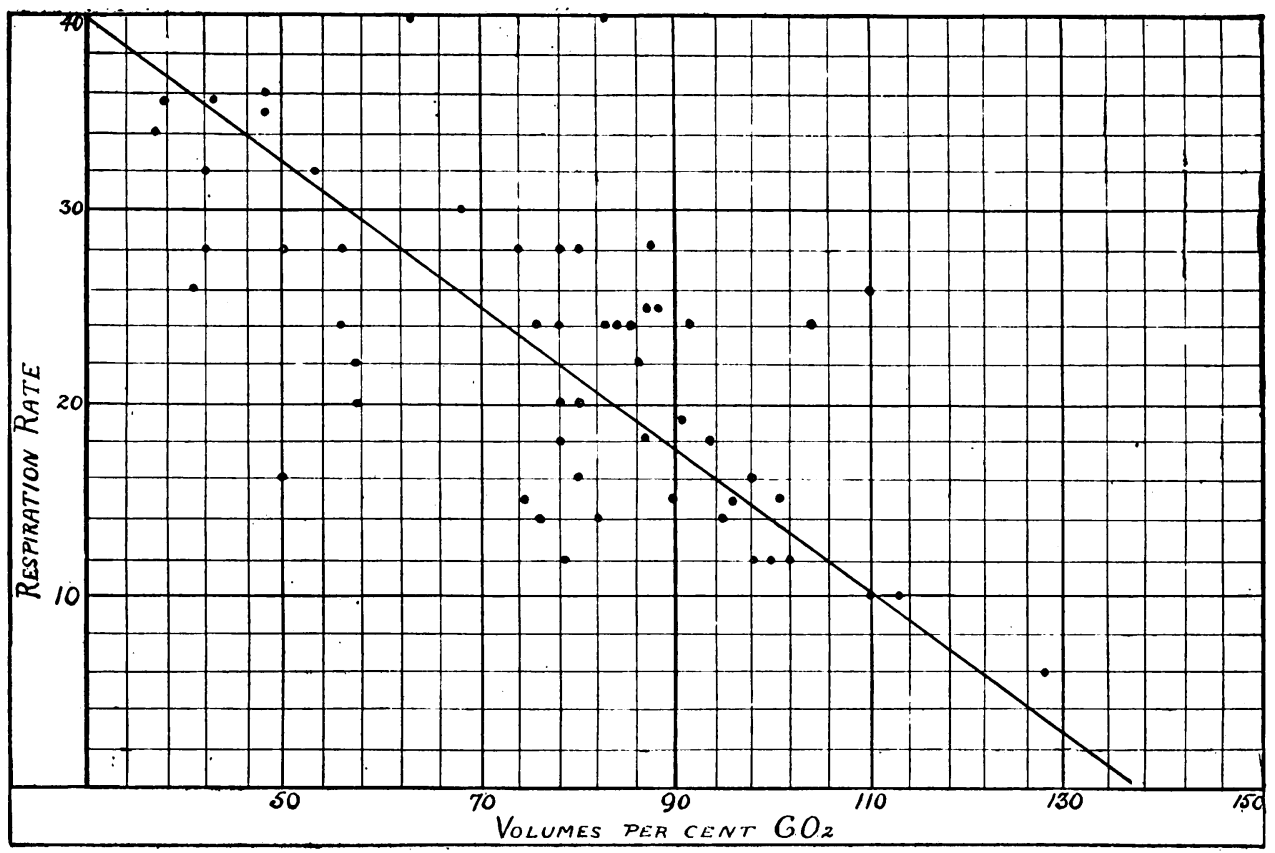

Relationship of the total $\mathrm{CO}_{2}$ Content and Respiration. One of the most striking correlations among our findings is that between the total $\mathrm{CO}_{2}$ content of the blood and the respiratory rate. This is all the more striking when one remembers that it is the total respiratory exchange and not merely the rate of breathing which is of significance. Further, it is not the total $\mathrm{CO}_{2}$ but rather the ratio of the free and combined $\mathrm{CO}_{2}$, which is the regulating factor in respiration. In Chart I are plotted individual observations of the total $\mathrm{CO}_{2}$ content of the blood against the respiratory rate at the time of withdrawal of the blood. The slower the respiratory rate, the greater is the increase in $\mathrm{CO}_{2}$. There are certain anomalous findings on the chart but when one remembers the possibility 
of tachypnœa resulting from oxygen deficiency, it can be readily understood that such results are only to be expected. In Table 3 , the se results are grouped into six averages which indicate clearly the strong correlation.

TABLE 3.

Showing CORRELATION BETWEeN $\mathrm{CO}_{2}$ CONTENT OF BLOOD AND RESPIRATORY RATE IN CASES OF PYLORIC STENOSIS.

\begin{tabular}{|c|c|c|c|c|c|c|}
\hline Group & 1 & 2 & 3 & 4 & 5 & 6 \\
\hline Average respiration rate (per min.) ... & 8 & $13 \cdot 8$ & $18 \cdot 1$ & $23 \cdot 4$ & $27 \cdot 8$ & $38 \cdot 9$ \\
\hline Average $\mathrm{CO}_{2}$ content (vol. per cent.) & $138 \cdot 8$ & $108 \cdot 6$ & 99 & 99 & $87 \cdot 7$ & $65 \cdot 2$ \\
\hline
\end{tabular}

This relationship between the $\mathrm{CO}_{2}$ capacity and slow breathing apparently only holds good in patients suffering from pyloric stenosis. During the past three years, it has been our custom to pay particular attention to respiratory rates in other conditions than pyloric stenosis, and not infrequently we have observed great reductions in rate, but in no instance was the $\mathrm{CO}_{2}$ content of the blood raised appreciably above the normal. These findings are seen in Table 4. In the case of J.L. suffering from encephalitis with a respiratory rate of 8 per minute, the chlorides $\left(\mathrm{C}^{1}\right)$ were $240 \mathrm{mgm}$. per cent., the nonprotein nitrogen was $35 \mathrm{mgm}$. per cent. and the $\mathrm{pH}$ was $7 \cdot 25$ (i.e. an acidosis). One important point in the clinical differentiation of these two types of slow breathing is the degree of cyanosis present. The cases in Table 4 invariably showed a fair degree of cyanosis while the cases of pyloric stenosis as a rule none at all. The explanation of this is not clear. Theoretically, the high $\mathrm{CO}_{2}$ content should predispose to anoxæmia, since $\mathrm{CO}_{2}$ shifts the oxyhæmoglobin dissociation curve to the right, that is, the more $\mathrm{CO}_{2}$ present the less the degree of oxygen saturated, and hence the greater the amount of reduced hæmoglobin.

TABLE 4.

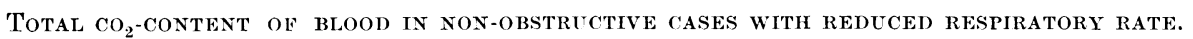

\begin{tabular}{|c|c|c|c|c|c|c|c|c|}
\hline \multirow{2}{*}{$\begin{array}{l}\text { Case } \\
\text { J.L. }\end{array}$} & \multicolumn{6}{|c|}{ Diagnosis } & \multirow{2}{*}{$\begin{array}{c}\begin{array}{c}\text { Respiratory } \\
\text { rate (per min.) }\end{array} \\
14\end{array}$} & \multirow{2}{*}{$\begin{array}{c}\begin{array}{c}\text { Total } \mathrm{CO}_{2} \\
\text { (vol. per cent.) }\end{array} \\
56 \cdot 5\end{array}$} \\
\hline & Encephalitis & thargic & & $\ldots$ & $\ldots$ & $\ldots$ & & \\
\hline , & ," & , & $\ldots$ & ... & $\ldots$ & $\ldots$ & 8 & $62 \cdot 7$ \\
\hline , &, & & $\ldots$ & $\ldots$ & $\ldots$ & $\ldots$ & 8 & $67 \cdot 0$ \\
\hline M.M. & Cerebral hæm & rrhage & $\ldots$ & $\ldots$ & $\ldots$ & $\ldots$ & 10 & 57.5 \\
\hline R.M. & Prematurity & & $\ldots$ & $\ldots$ & $\ldots$ & $\ldots$ & 10 & $55 \cdot 0$ \\
\hline W.D. & Congenital he & rt diseas & & $\ldots$ & $\ldots$ & $\ldots$ & 4 & $52 \cdot 7$ \\
\hline J.R. & Prematurity & $\ldots$ & $\ldots$ & $\ldots$ & $\ldots$ & $\ldots$ & 12 & $60 \cdot 6$ \\
\hline J.G. & Meningitis & $\ldots$ & $\ldots$ & $\ldots$ & $\ldots$ & $\ldots$ & 12 & $57 \cdot 1$ \\
\hline M.C. & Pyuria ... & $\ldots$ & $\ldots$ & $\ldots$ & $\ldots$ & $\ldots$ & 18 & $55 \cdot 4$ \\
\hline
\end{tabular}


Relationship of the $\mathrm{CO}_{2}$ Content and Vomiting. The relationship between the total $\mathrm{CO}_{2}$ content of the blood and the severity of the vomiting is not close. It is, however, admittedly difficult to gauge the amount of vomitus and, what is even more important, the character of the vomitus, for example, the amount of chlorine present. An attempt has been made in Table 5 to correlate these two factors but we feel that too much stress should not be laid on it. When the records of individual patients are examined, it is found that, occasionally, the total $\mathrm{CO}_{2}$ content of the blood may remain high despite the fact that there had been no vomiting for several days prior to its estimation. This might be explained by the length of time which it takes for the blood to return to its normal composition. But in one patient, vomiting can have played absolutely no part in producing the increase in the $\mathrm{CO}_{2}$. This was the case already referred to, who, although suffering from pyloric stenosis, did not vomit either previous to admission or during a four weeks' stay in hospital. The total $\mathrm{CO}_{2}$ content of the blood reached the value of 102 vol. per cent., and the $\mathrm{CO}_{2}$ dissociation curve showed clearly its increased capacity of holding $\mathrm{CO}_{2}$.

TABLE 5 .

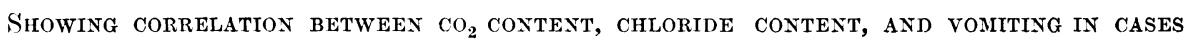
OF PYLORIC STENOSIS

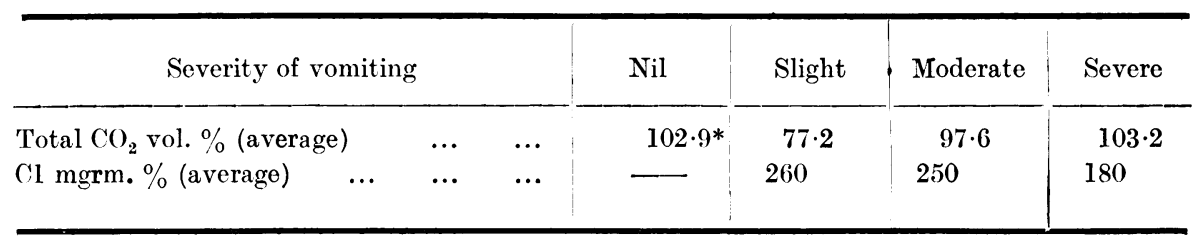

* Only two cases.

In patients suffering from vomiting, and even from severe vomiting, due to causes other than pyloric stenosis, one rarely if ever finds the $\mathrm{CO}_{2}$ content raised. It must be remembered, however, that it is not the mere presence of vomiting but rather the nature and amount of the material vomited which is of significance. One nevertheless feels justified in concluding from a study of this series of pyloric stenosis that the severity of the vomiting is no measure of the metabolic disturbance as evidenced by the increase in the total $\mathrm{CO}_{2}$ content of the blood.

The total $\mathrm{CO}_{2}$ content of the blood and the general nutrition. An association between the fall of the $\mathrm{CO}_{2}$ to normal and the increase in the weight of the infant is illustrated in Chart II. This correlation holds gocd only for the same individual and therefore an isolated observation on the $\mathrm{CO}_{2}$ content cannot be taken as a prognostic sign. A great increase in the $\mathrm{CO}_{2}$ content does not necessarily mean a worse prognosis than a moderate rise. Furthermore, there does not seem to be any relationship between the level of the $\mathrm{CO}_{2}$ and the length of time the vomiting has existed.

The association between the fall in $\mathrm{CO}_{2}$ and the improvement in general nutrition was recognized to be simply the result of concomitant events and not dependent on cause and effect. Nevertheless, an attempt was made in a few 
instances to influence the $\mathrm{CO}_{2}$ content of the blood and determine whether such change resulted in clinical improvement. In one case, by means of transfusion, the $\mathrm{CO}_{2}$ value was reduced from 98 vol. per cent. before transfusion to $70 \cdot 2 \mathrm{vol}$. per cent. five minutes after transfusion. The donor's blood, of which 110 c.cm. were given along with $40 \mathrm{c} . \mathrm{cm}$. normal saline, contained $62 \cdot 1$ vol. per cent. $\mathrm{CO}_{2}$. Assuming the volume of the infant's blood to be $200 \mathrm{c.cm}$. (weight of infant $3 \cdot 1$ kilos) then $\mathbf{7 5 . 5}$ vol. per cent. represents the value one would calculate from a mixture of the two bloods and the saline. There was no apparent change in

CHAR'T II.

To show increase in Weight and Fall in total $\mathrm{CO}_{2}$ content of Blood in case of infant J. B.

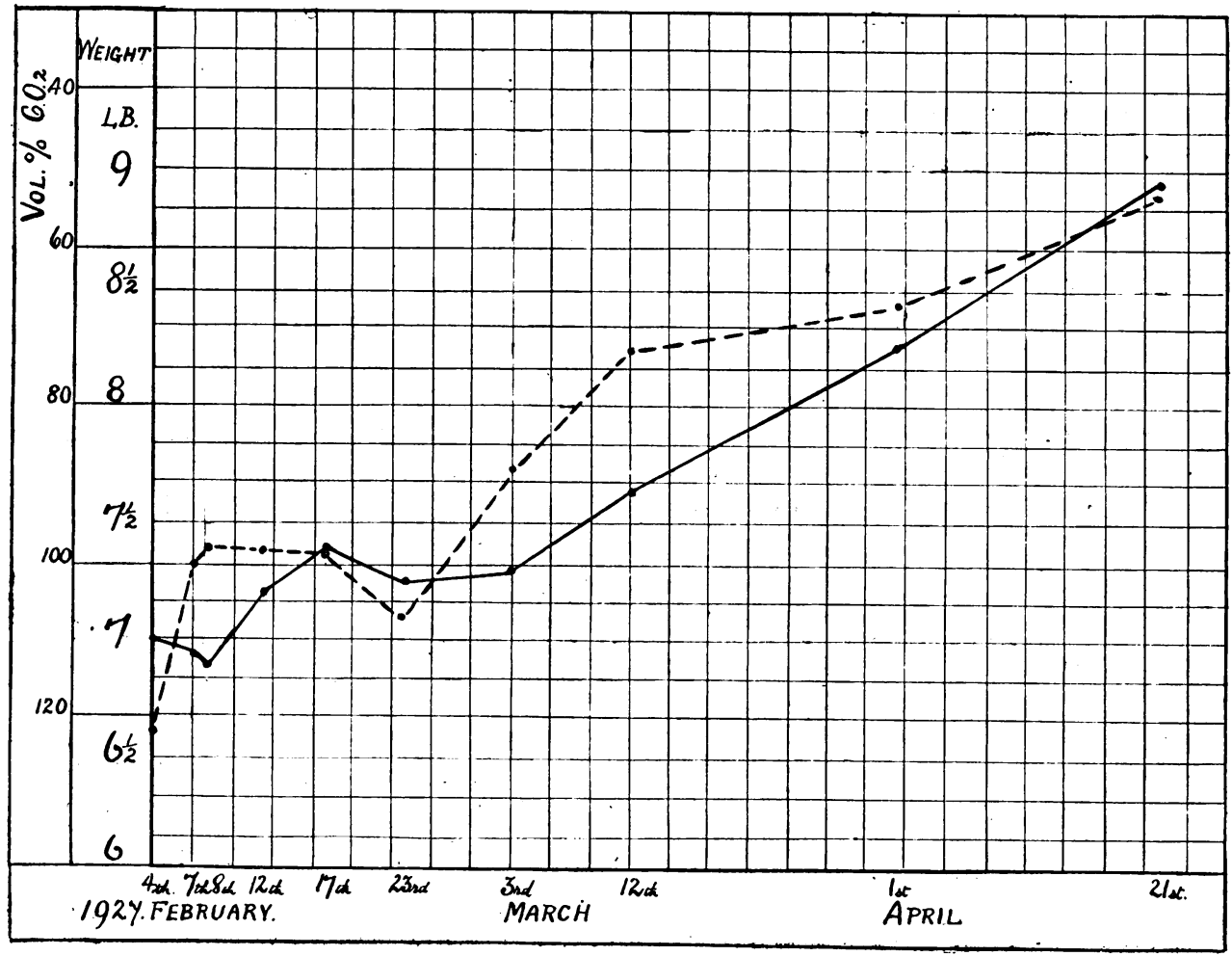

the clinical condition of the infant and this lowering of the $\mathrm{CO}_{2}$ content was not permanent, as within four days it had risen again to $97 \cdot 8$ vol. per cent. In another case, the infant's blood was withdrawn twenty hours after transfusion but the $\mathrm{CO}_{2}$ content was practically unaltered from the pre-transfusion value. In two cases calcium chloride was given. In one the $\mathrm{CO}_{2}$ content was reduced from 110 vol. per cent. to $62.3 \mathrm{vol}$. per cent. although the clinical condition was unchanged, while in the other, the $\mathrm{CO}_{2}$ content was unaffected.

The $\mathrm{CO}_{2}$ content of the blood and its reaction. The question arises whether the increase in the $\mathrm{CO}_{2}$ content is indicative of a non-gaseous alkalosis or of a gaseous acidosis. The $\mathrm{CO}_{2}$ dissociation curve of the blood shows a shift 
to the left, i.e., the capacity to hold $\mathrm{CO}_{2}$ is increased, a finding equally characteristic of either of the above two conditions. It is obvious that if the depressed breathing is primary, the condition is one of gaseous acidosis such as occurs in subnormal activity of respiratory function. If, however, the increase in $\mathrm{CO}_{2}$ content is the cause of the diminished respiratory exchange, the condition must be one of non-gaseous alkalosis. Ellis ${ }^{8}$ has given details of the findings in two cases of high intestinal obstruction in both of whom there was an alkalæmia, as indicated by the $\mathrm{pH}$ of the blood. In a few instances in our series, the $\mathrm{pH}$ of the blood has been determined. The figures obtained are found in Table 6. It will be seen that if any change from the normal does occur, it is toward the alkaline side. In contrast with this finding, it is interesting to note the $\mathrm{pH}$ figure in the case of J.L. suffering from encephalitis. Here, although the respiratory rate was only eight per minute, the total $\mathrm{CO}_{2}$ content was 67 vol. per cent. and the $\mathrm{pH} 7 \cdot 25$. This slightly increased $\mathrm{CO}_{2}$ value and the $\mathrm{pH}$ on the acid side of normality indicate a gaseous acidosis. One can, therefore, conclude that in pyloric stenosis, the disturbance of the acid base balance is toward the alkaline side and that the change in the respiratory volume is secondary.

TABLE 6.

pH FINDINGS AND THE RELATIONSHIP TO $\mathrm{CO}_{2}$ CONTENT OF BLOOD.

\begin{tabular}{|c|c|c|c|c|c|c|c|c|}
\hline \multirow{2}{*}{$\begin{array}{l}\text { Name } \\
\text { J.C. }\end{array}$} & \multicolumn{5}{|c|}{ Diagnosis } & \multirow{2}{*}{$\begin{array}{c}\text { Respiratory } \\
\text { rate (per min.) } \\
?\end{array}$} & \multirow{2}{*}{$\frac{\begin{array}{l}\text { Total } \mathrm{CO}_{2} \\
(\text { vol. } \%)\end{array}}{140 \cdot 0}$} & \multirow{2}{*}{$\begin{array}{c}\mathrm{pH} \\
7 \cdot 76\end{array}$} \\
\hline & Pyloric stenosis & $\therefore \ldots$ & $\ldots$ & $\ldots$ & $\ldots$ & & & \\
\hline R.R. & .. & $\ldots$ & $\cdots$ & $\cdots$ & $\cdots$ & 15 & $110 \cdot 0$ & $7 \cdot 33$ \\
\hline W.B. & ,. & $\ldots$ & $\ldots$ & $\ldots$ & $\ldots$ & $\because$ & $73 \cdot 2$ & $7 \cdot 35$ \\
\hline $\mathrm{M} \cdot \mathrm{L}$ & , & $\ldots$ & $\ldots$ & $\ldots$ & $\ldots$ & 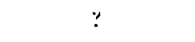 & $53 \cdot 4$ & $7 \cdot 39$ \\
\hline M.R. & , & $\ldots$ & $\ldots$ & $\ldots$ & $\ldots$ & 24 & $110 \cdot 0$ & $7 \cdot 52$ \\
\hline J.I. & Encephalitis let & tharg & $\ldots$ & $\ldots$ & $\ldots$ & 8 & $67 \cdot 0$ & $7 \cdot 25$ \\
\hline
\end{tabular}

The presence of such a degree of alkalosis as suggested by the high $\mathrm{CO}_{2}$ values would lead one to expect the frequent occurrence of tetany. Signs of increased muscular irritability, as a matter of fact, have been reported frequently in high intestinal obstruction in the adult, as well as that produced experimentally in dogs. Convulsions, although said to be common by some observers, are in our experience rare in pyloric stenosis of infancy. In only two cases was there any such history obtained. In one of these laryngismus was an associated symptom. In no case tested was the neuro-muscular excitability increased as one might have expacted. The reason for this absence of the signs of tetany may in part be due to the increased blood calcium content which we have found as high as $14 \mathrm{mgrm}$. per cent.

The cause of the alkalosis presumably is the increased amount of available base resulting from a deficiency of chlorine. It becomes necessary for the $\mathrm{CO}$, content to rise in order to combine with this base. 
Fig. I (a) adapted from Gamble's paper shows that $\mathrm{CO}_{2}$ is one of the acid radicles combined with fixed base, the others being $\mathrm{Cl}, \mathrm{HPO}_{4}, \mathrm{SO}_{4}$, organic acid and protein. Of all these acid radicles, $\mathrm{CO}_{2}$ is the most mobile and elastic, being very easily retained or dispensed with by the activity of the respiratory centre. In Fig. I (b) is represented the state of affairs found in pyloric stenosis. It will be seen that the excess of $\mathrm{CO}_{2}$ makes up for the deficit of $\mathrm{Cl}$. The results recorded in Table $\mathrm{I}$ indicate that this balancing of diminished $\mathrm{Cl}$ by increase of $\mathrm{CO}_{2}$ although generally complete is not necessarily the rule. Unfortunately, we have not obtained com plete data in any one case. The figures for fixed base indicate that it is practically unchanged. Our data for acid radicles other than

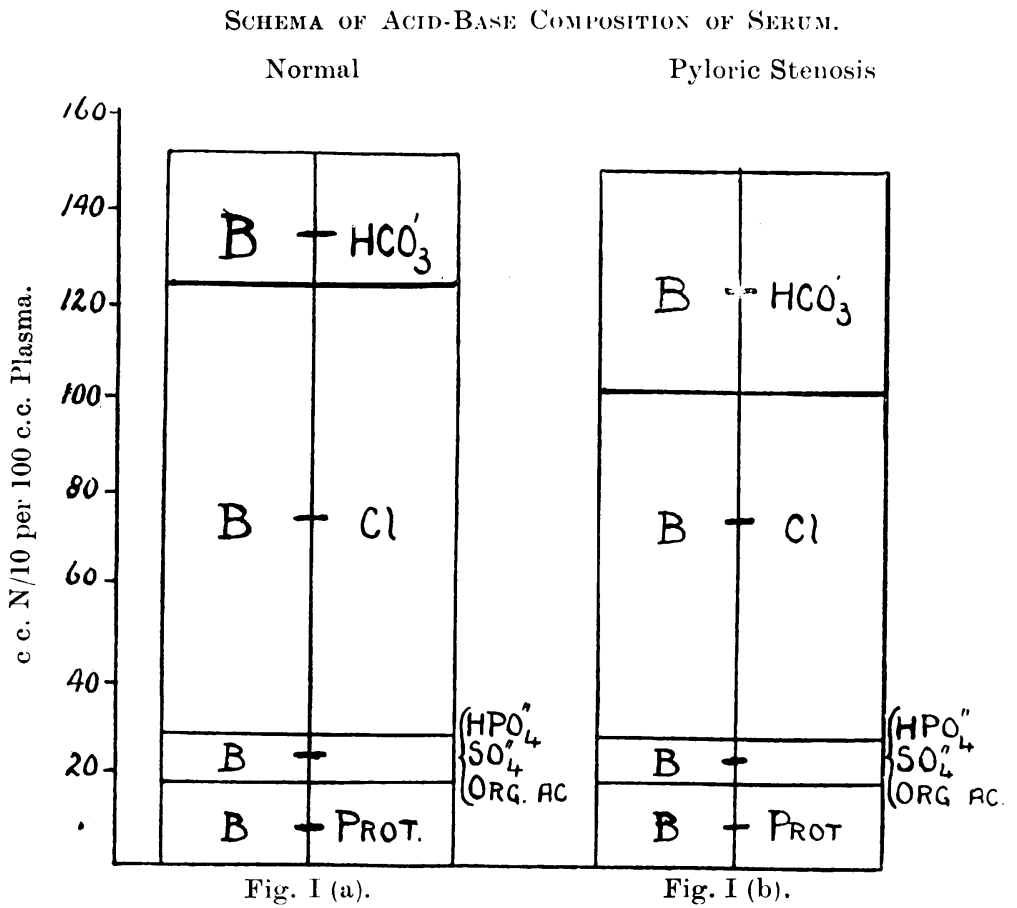

$\mathrm{Cl}$ and $\mathrm{CO}_{2}$ are scanty. In two cases we found values for inorganic phosphorus of 10.5 and $11.6 \mathrm{mgm}$. per cent. respectively. Atchley and Benedict ${ }^{10}$ maintain that they can demonstrate an increase in the phosphate, sulphate and protein of the blood sufficient to account for the diminution in the $\left(\mathrm{Cl}+\mathrm{CO}_{2}\right)$ value. Gamble $^{6}$ postulates an increase in organic acid. The ketone content of the blood has not been estimated in this series but frequently we have noted a fair degree of ketonuria. This may be consequent on the inanition (starvation), or due to alkalamia or to both factors, and it is quite probable that these ketone acids take part to a certain extent in the compensation for the diminished $\mathrm{Cl}+\mathrm{CO}_{2}$ content.

The behaviour of the chlorides:-The fall in the blood chloride is one of the most constant changes in the biochemical findings. The reduction seems to 
bear some relationship to the severity of the vomiting (Table 5), even although this relationship is masked by the inability to determine the actual amount of vomitus and its chloride content. The urine contains but a trace of chlorine, which is to be expected if chlorine is a threshold substance. Following the intravenous injection of a solution of normal saline practically all the water is excreted whereas approximately 80 per cent. of the chlorine is retained. In infants suffering from vomiting from other causes, only about 10 per cent. is retained. These results are shown in Table 7. In the two infants who were vomiting from causes other than pyloric stenosis, the amount of $\mathrm{Cl}$ retained was 11.8 and 7.0 per cent. respectively. In the cases of pyloric stenosis, 80.7 and 81.8 per cent. were retained. After operation in one case only 2 per cent. was retained which indicates that the condition was relieved. This retention of $\mathrm{Cl}$ in the examples of pyloric stenosis indicates definitely a chlorine hunger of the tissues. Hartmann and Smyth ${ }^{1}$ maintain that severe vomiting may also lead to a depletion of the blood chloride. While it is true that the chloride may be somewhat reduced, it appears evident that the metabolism of chlorine in non-obstructive cases presents a different picture from that in pyloric stenosis.

TABLE 7.

Chloride content of urine and percentage absorption of chloride in Cases of pyloric STENOSIS AND NON-OBSTRUCTIVE VOMITING.

\begin{tabular}{|c|c|c|c|c|c|c|}
\hline \multirow[t]{2}{*}{ Name } & \multirow{2}{*}{$\begin{array}{c}\text { Volume } \\
\text { of } \\
\text { urine }\end{array}$} & \multirow{2}{*}{$\begin{array}{l}\text { Amount of } \\
\text { saline } \\
\text { injected } \\
\text { (cc.) }\end{array}$} & \multicolumn{2}{|c|}{ Chloride in urine } & \multirow{2}{*}{$\begin{array}{r}\text { Percentage } \\
\text { of chloride } \\
\text { retained }\end{array}$} & \multirow[t]{2}{*}{ Remarks } \\
\hline & & & Per cent. & Total & & \\
\hline W.B. & $\begin{array}{r}91 \\
205\end{array}$ & $\frac{-}{100}$ & $\begin{array}{l}0.585 \\
0.647\end{array}$ & $\begin{array}{l}0 \cdot 532 \\
1 \cdot 326\end{array}$ & $\overline{11 \cdot 8}$ & $\begin{array}{l}\text { Feeding case. } \\
\text { Vomiting }+\end{array}$ \\
\hline R.W. & $\begin{array}{l}370 \\
450\end{array}$ & $\overline{80}$ & $\begin{array}{l}0 \cdot 303 \\
0 \cdot 420\end{array}$ & $\begin{array}{l}1 \cdot 120 \\
1 \cdot 890\end{array}$ & $\overline{7 \cdot 0}$ & $\begin{array}{l}\text { Meningitis. } \\
\text { Vomiting }+\end{array}$ \\
\hline J.R. & $\begin{array}{l}265 \\
330\end{array}$ & $\overline{60}$ & $\begin{array}{l}0.048 \\
0.07\end{array}$ & $\begin{array}{l}0 \cdot 128 \\
0 \cdot 232\end{array}$ & $\overline{80 \cdot 7}$ & Pyloric stenosis. \\
\hline C.C. & $\begin{array}{l}232 \\
350 \\
784 \\
920\end{array}$ & $\begin{array}{l}-\overline{100} \\
\overline{100}\end{array}$ & $\begin{array}{c}\text { nil } \\
0 \cdot 047 \\
0 \cdot 738 \\
0 \cdot 725\end{array}$ & $\begin{array}{l}\text { nil } \\
0 \cdot 164 \\
5 \cdot 786 \\
6 \cdot 670\end{array}$ & $\begin{array}{c}\overline{81 \cdot 8} \\
\frac{-}{2 \cdot 0}\end{array}$ & $\begin{array}{c}\text { Pyloric stenosis } \\
\text { (before operation) } \\
\text { (After operation). }\end{array}$ \\
\hline
\end{tabular}

\section{Discussion.}

Several views have been put forward as to the cause of the biochemical picture in high intestinal obstruction. That most commonly held is the one suggested by MacCallum ${ }^{3}$ and elaborated by Gamble ${ }^{6}$ and his colleagues. They believe the primary factor to be the loss of chlorine, base, and water by vomiting. This impoverishment of body chlorine is compensated for by the retention of 
$\mathrm{CO}_{2}$ with consequent production of an alkalosis. Haden and $\mathrm{Orr}^{5}$, however, previously pointed out that a similar condition could be produced by experimental pyloric obstruction in rabbits, animals which do not vomit. But Gamble and McIver ${ }^{11}$ were able to show that in rabbits there followed a very marked dilatation of the stomach into which the chloride was secreted and virtually lost to the body despite the absence of vomiting. This view certainly seems to explain all the experimental findings in animals. Ellis records the case of a patient suffering from carcinomatous obstruction of the pylorus with symptoms of tetany and biochemical evidence of a severe alkalæmia. There was no free hydrochloric acid in the gastric juice. The vomiting was severe, entailing in all probability a great loss of neutral chlorides. An explanation to fit this case is found in the fact that the reserve of fixed base is greater than that of chlorine so that the former is maintained at a more or less normal level in the blood while the chlorine content falls despite the fact that equivalent amounts of base and chlorine are lost in the vomitus.

In the analysis of the results in this series there is undoubtedly some relationship between the depletion of the blood chloride and the severity of the vomiting, and this in spite of the difficulty in estimating the latter factor and the great variation which is bound to exist in the chloride content of the tissues of different individuals. There is, however, one case in our series which does not permit of explanation on the basis of this hypothesis. This is the case of the infant referred to previously who did not vomit. He was admitted to the ward at the age of four weeks with the diagnosis of mental deficiency and pyloric stenosis. Visible peristalsis was readily demonstrated and there was a tumour palpable in the region of the pylorus. This infant was in the ward for four weeks and finally succumbed to a secondary infection. At the post-mortem examination, typical hypertrophic pyloric stenosis was revealed. During his residence in hospital he took his feeds well but never once vomited. He was not constipated. He presented the typical clinical picture of a severe alkalosis and the total $\mathrm{CO}_{2}$ content of the blood was 102 vol. per cent. The respiratory rate averaged about 12 per minute. Unfortunately the blood chlorides were not estimated. It is difficult to understand how the depletion of the chloride resulted in this particular instance. It is highly improbable that the chlorine lost to the body during the four weeks' stay in hospital could have been lost via the gastric secretions. We have no information regarding the renal efficiency in this case.

Another hypothesis which has been advanced is that the condition is in part due to renal inefficiency. The chief evidence in favour of this view is the presence of an increased non-protein nitrogen content of the blood. At first this increase was attributed to increased destruction of tissue proteins as a result of toxæmia (Cooke, Rodenbaugh and Whipple ${ }^{12}$ ). Brown, Eusterman, Hartmann and Rowntree ${ }^{7}$ suggestcd that the increase in the blood urea is the result of inefficient renal activity and concluded that the tetany-like symptcms are really uræmic in nature. In their paper they give details of the macroscopic and microscopic appearances of toxic nephritis occurring in six cases of fatal pyloro-duodenal obstruction. Ellis supported this view by his finding of a 
low percentage excretion of urea despite a high blood urea, and by the fact that an alkalosis can be produced by administration of alkali only when the renal function is impaired. In one of the two cases reported by him there was pyæmia involving the kidney and in both there was noted the excretion of an acid urine $(\mathrm{pH}=5 \cdot 6)$ associated with an over-alkaline plasma.

Hartmann and Smyth ${ }^{1}$ have given figures which lead them to believe that the increase in N.P.N. is for the purpose of maintaining the normal osmolar concentration. They calculated the molecular value of the excess N.P.N. on the assumption that it is all urea and that two molecules of urea constitute one milli-equivalent. In Table 1 we have attempted to do the same and the findings occasionally lend some support to their view. Especially is this the case in the patient W.A. whose blood was analysed on two separate occasions. On the second occasion there was a more marked diminution in chloride with an increase in the $\mathrm{CO}_{2}$ which did not compensate for the extra chloride deficiency. On calculating the value for the excess N.P.N. it is found that the deficiency is almost exactly balanced by the rise in N.P.N. Many of the other results, however, fail to support the view. Thus in the blood of A.M. or W.G. the decrease in the combined $\mathrm{CO}_{2}$ plus $\mathrm{Cl}$ value is not associated with any increase in the non-protein nitrogen. Two possible explanations of these discrepancies suggest themselves, first in the excessive formation of ketone bodies and second, an increase in the base binding power of the proteins. Atchley and Benedict ${ }^{10}$ have shown that owing to anhydræmia, the serum protein is increased in amount. Its base-binding power depends in addition on the $\mathrm{pH}$ of the medium. The more alkaline the plasma the greater is the capacity of the protein to hold base.

A third view was put forward in a series of papers by Haden and $0 \mathrm{rr}^{5}$. They suggested that the chlorine was fixed in the tissues by some toxin and supported this view by the beneficial results obtained from the administration of chlorides. This can be equally well explained on Gamble's theory which Haden and $\mathrm{Orr}^{14}$ in a recent paper apparently accept. Drake and Tisdall ${ }^{13}$ have obtained similar resulte to those found in experimental obstruction by the injection of histamine. They found that there was no relationship between the decreased $\mathrm{Cl}$ content and the degree of intoxication which was, however, closely related to the concentration of non-protein nitrogen. Further they concluded that the decreased $\mathrm{Cl}$ content was not due to loss in the gastric secretions since apomorphine which led to a greater loss of $\mathrm{Cl}$ in the vomitus did not induce any diminution in the plasma $\mathrm{Cl}$. Our results do not throw any light on this point.

\section{Conclusions.}

1. Pyloric stenosis in infancy is associated with an alkalosis presumably produced by a loss of the acid radicule chlorine from the body. The loss of chlorine is roughly related to the severity of the vomiting. The total $\mathrm{CO}_{2}$, content varies inversely with the blood chlorides. The fixed base as a rule is unaltered or at the most only slightly diminished. 
2. The rise in $\mathrm{CO}_{2}$ is evidenced by a depression of the breathing (Biot type of respiration), which affords a ready method of its clinical recognition.

3. Certain cases occur which do not permit of the explanation of loss of chlorine by vomiting. It would appear that in such cases a nother factor, possibly impairment of renal function is present.

4. The conclusion that the rise in the non-protein nitrogen occurs in order to restore the osmolar concentration of the blood is not always justified.

We desire to express our thanks to the Medica! Research Council for their help in this work.

Analytical methods used:-Blood-Total $\mathrm{CO}_{2}-$ Haldane $^{15}$ : ChlorideWhitehorn $^{16}$ : Non-protein Nitrogen-Folin-Wu method: Fixed BaseStadie and Ross ${ }^{17}$ : Calcium-Kramer and Tisdall's method: PhosphorusTisdall's method : $\mathrm{pH}-\cdots$ Dale and Evans ${ }^{18}$. Urine chloride-Volhard's method.

1. Hartmann, A. F., \& Smyth, F. S., Amer. Jour. Dis. Child., Chicago, 1926, XXXII, 1.

2. McCann, W. S., Jour. Biol. Chem., N.Y., 1918, XXXV, $5 \tilde{5} 3$.

3. McCallum, W. G., Lintz. J., Vermilye, H. N., Leggett, T. H., \& Boas, E., Bull. J. Hopk. Hos., Baltimore, 1920, XXXI, 1.

4. Hastings, A.B., Murray, C. D., \& Murray, A. A., Jour. Biol. Chem., N. Y., 1918, XX XVI, 223.

5. Haden, R. L., \& Orr, T. G., Jour. Exper. Med., N.Y., 1923, XXXVII, 377.

6. Gamble, J. L., \& Ross, S. G., Jour. Clin. Inves., Baltimore, 1924-25, I, 403.

7. Brown, G. E., Eusterman, G. B., Hartmann, H. R.\& Rowntree, L. G., Arch. Inter. Med., Chicago, 1923, XXXII, 425.

8. Ellis, A., Quart. Jour. Med., Oxford, 1923-24, XVII, 405.

9. Hardt, C. L., \& Rivers, A. B., Arch. Int. Med., Chicago, 1923, XXXI, 171.

10. Atchley, D. W. \& Benedict, E. M., Jour. Biol. Chem., N.Y., 1927, LXXV, 679.

11. Gamble, J. L., \& McIver, M. A., Jour. Clin. Invest., Baltimore, 1924-25, I, 531.

12. Cooke, J. V., Rodenbaugh, F. H.,\& Whipple, G. H., J. Exp. Med., N.Y., 1916, XXIII, 717.

13. Drake, T. G. H., \& Tisdall, F. F., Jour. Biol. Chem., N.Y., 1926, LXVII, 91.

14. Haden, R. L., \& Orr, T. G., Jour. Amer. Med. Assoc., Chicago, 1928, XCI, 1529.

15. Haldane, J. s., Jour. Path \& Bact., Edinburgh, 1920, XXIII, 443.

16. Whitehorn, J. C., Jour. Biol. Chem., N.Y., 1921, XLV, 449.

17. Stadie, W. (., \& Ross, E. C., Jour. Biol. Chem., N.Y., 1925, XLV, 735.

18. Dale, H. H., \& Evans, C. L., Jour. Physiol., London, 1920, LIV, 167. 